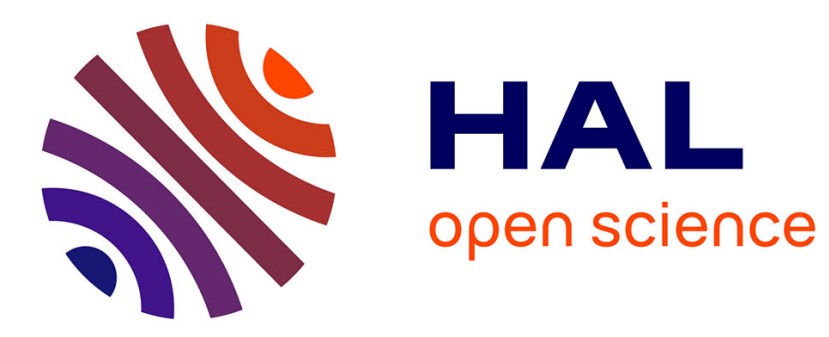

\title{
Poly(phosphorhydrazone) Dendrimers and Other Phosphorus-containing Dendrimers
}

\author{
Anne-Marie Caminade
}

\section{To cite this version:}

Anne-Marie Caminade. Poly(phosphorhydrazone) Dendrimers and Other Phosphorus-containing Dendrimers. Michael Malkoch; Sandra Garcia Gallego. Dendrimer Chemistry: Synthetic Approaches Towards Complex Architectures, Royal Society of Chemistry, pp.146-182, 2020, 978-1-78801-132-7. 10.1039/9781788012904-00146. hal-02880003

\section{HAL Id: hal-02880003 https://hal.science/hal-02880003}

Submitted on 4 Nov 2020

HAL is a multi-disciplinary open access archive for the deposit and dissemination of scientific research documents, whether they are published or not. The documents may come from teaching and research institutions in France or abroad, or from public or private research centers.
L'archive ouverte pluridisciplinaire HAL, est destinée au dépôt et à la diffusion de documents scientifiques de niveau recherche, publiés ou non, émanant des établissements d'enseignement et de recherche français ou étrangers, des laboratoires publics ou privés. 


\section{CHAPTER 7}

Poly(phosphorhydrazone) dendrimers and other phosphorus-containing dendrimers

Anne-Marie Caminade ${ }^{\mathrm{a} *}$

${ }^{a}$ Laboratoire de Chimie de Coordination du CNRS, 205 Route de Narbonne, 31077 Toulouse Cedex 4, France

*Corresponding contributor. E-mail: anne-marie.caminade@1cc-toulouse.fr 


\begin{abstract}
This chapter will focus on the methods of synthesis of phosphorus-containing dendritic architectures, mainly of phosphorhydrazone type, coming from our group, but also on other types of phosphorus dendrimers coming from other laboratories. The different types of cores, branches, and surface functionalities of phosphorhydrazone dendrimers will be displayed. An overview of the field will be given, concerning not only regular dendrimers, but also dendrimers with layered architectures, dendrons, and various types of less symmetrical dendritic architectures, all based on phosphorus derivatives. The properties of these compounds will be briefly highlighted in the last part of this chapter, concerning in particular catalysis, nanomaterials, and biology/nanomedicine.
\end{abstract}




\subsection{Introduction}

Phosphorus-containing dendrimers are defined as dendrimers including at least one phosphorus atom at all branching points, whatever the type of linkages used between two layers of phosphorus atoms. These dendrimers pertain to the large family of inorganic dendrimers, which includes also silicon-containing dendrimers. Inorganic dendrimers have some special properties, ${ }^{1}$ compared to classical organic dendrimers, built in particular with a nitrogen atom at each branching point, such as for instance the well-known PAMAM dendrimers.

The first method of synthesis of any type of phosphorus-containing dendrimers was described by Rengan and Engel in 1991, using a divergent process. ${ }^{2}$ These dendrimers are constituted of a phosphonium at each branching point ( 4 carbon atoms around the positively charged phosphorus atoms), multiplying by 3 the number of terminal groups at each generation (instead of 2 in most cases, as will be seen later) and they have been synthesized up to the third generation (compound $\mathbf{1}$ in Figure 7.1). We have described shortly after, in 1994, the first example of neutral phosphorus-containing dendrimers, based on phosphorhydrazone linkages. ${ }^{3}$ As this type of dendrimers will be the main topic of this chapter, we will not describe them here, but rather consider the types of phosphorus-containing dendrimers produced in other groups than mine, and ranked depending on the atoms linked to phosphorus (P-C, P-O, or P-N linkages).

\subsection{Phosphorus-containing dendrimers with a single type of atoms around phosphorus}

\subsubsection{Dendrimers with only P-C linkages}

As indicated above, the very first type of phosphorus-containing dendrimers was based on P-C linkages. A few other types of dendrimers based on such linkages have been described. DuBois et al. obtained in 1994 a small dendrimer (generation 2, compound 2) constituted of phosphines at each branching points, by a radical addition of primary phosphines to the vinyl group of phosphonates, followed by reduction of the phosphonates by lithium aluminium hydride, to afford again primary phosphines. ${ }^{4}$ Larger phosphine dendrimers (generation 3, compound 3) were described in 1999 by Kakkar et al. The first step was the aminosilanization of alcohol end groups; the second step was a controlled acid-based hydrolysis of the aminosilanes by a single $\mathrm{OH}$ function of $\mathrm{P}\left[\left(\mathrm{CH}_{2}\right)_{3} \mathrm{OH}\right]_{3}$. Despite the possibility of multiple reactions, characterization indicated that these compounds were dendrimers and not hyperbranched compounds. The corresponding rhodium complexes were obtained either by complexation of the free phosphine dendrimers or using a complexed phosphine instead of the free phosphine during the synthesis of the dendrimer. ${ }^{5}$ 
(Figure 7.1)

[Figure 7.1 near here]

\subsubsection{Dendrimers with only P-O linkages}

The first method of synthesis of dendrimers possessing phosphate groups as branching points was reported by Damha et al in $1993 .{ }^{6}$ These dendrimers were obtained by a convergent process in the solid phase, using an automated DNA synthesizer for chain extension. Adenosine phosphoramidate was added for creating the branching points by coupling two adjacent polymer-bound nucleotide chains. The dendrimers were isolated after cleavage from the solid phase. Various dendrimers based on thymidine and adenosine building blocks were synthesized by repetition of chain elongation and branching steps (compound 4 in Figure 7.1). The use of phosphoramidites as building blocks in solution was developed by Roy et al. in 1997, using a two-step divergent process. ${ }^{7}$ In a first step, a phosphoramidite bearing siloxane groups was coupled with alcohol end groups, followed by oxidation. The second step was the deprotection of the siloxane. Repeating twice both steps afforded the second generation, which was functionalized by $\mathrm{N}$-acetylgalactosamine (compound $\mathbf{5}$ in Figure 7.1). A related method was proposed by Salamonczyk et al. in 2000-2001, for obtaining a family of thiophosphate dendrimers. The first step was the reaction of a triol with a phosphoramidite possessing acetate groups, followed by oxidation with elemental sulphur. The second step was the deprotection of the acetates. The repetition of both steps was carried out up to the fifth generation. The same type of method is also usable for the synthesis of dendrimers possessing selenium, oxygen or boron hydride instead of sulphur linked to phosphorus ${ }^{8}$ (compound 6 in Figure 7.1). It is even possible to build original dendrimers possessing a different type of phosphate at each generation, chosen between $\mathrm{P}=\mathrm{S}, \mathrm{P}=\mathrm{Se}$, and $\mathrm{P}=\mathrm{O}$, affording layered dendrimers (compound 7 in Figure 7.1).

Recent examples of dendrimers with multiple P-O functions were based on cyclophosphazenes as core and branching points. S. Yesilot et al. published in 2014 the synthesis of a small (first generation) dendrimer based on the cyclotetraphosphazene. Despite being very small, this compound (8 in Figure 7.1), synthesized by a divergent process, possesses 56 terminal phenoxy groups. ${ }^{9}$ Using the cyclotriphosphazene, R. Roy et al. have proposed in 2015 the synthesis of a first generation dendrimer of type "onion peel" possessing long branches composed of different linkages, and carbohydrates terminal functions (compound 9 in Figure 7.1). One of the step during the synthesis was the so-called "click" reaction between azides and terminal alkyne, affording triazole rings. ${ }^{10}$ An early example using the cyclotriphosphazene both as core and branching points (compound $\mathbf{1 0}$ in Figure 7.1) was proposed by Labarre et al. in $1995,{ }^{11}$ but in view of the use of only a 
stoichiometric quantity of a diamine, and the absence of any characterization, these claims should be considered with caution.

\subsection{Phosphorhydrazone dendrimers and related compounds}

The most widely used method of synthesis of phosphorus-containing dendrimers is the one we described in 1994. ${ }^{3}$ It consists in the repetition of a two-step process using successively 4-hydroxybenzaldehyde in basic conditions and the phosphorhydrazide $\mathrm{H}_{2} \mathrm{NNMeP}(\mathrm{S}) \mathrm{Cl}_{2}$ (Figure 7.2.a). Both steps generate only $\mathrm{NaCl}$ and $\mathrm{H}_{2} \mathrm{O}$ as by-products and are quantitative. Starting from $\mathrm{P}(\mathrm{S}) \mathrm{Cl}_{3}$ as core, this process was carried out first up to generation $4,{ }^{3}$ then up to generation $7,{ }^{12}$ to generation $10,{ }^{13}$ and finally to generation $12,{ }^{14}$ which was the highest generation well characterized obtained for any type of dendrimers up to 2013. These reactions can be applied starting from various cores, in particular from $\mathrm{N}_{3} \mathrm{P}_{3} \mathrm{Cl}_{6}$ instead of $\mathrm{P}(\mathrm{S}) \mathrm{Cl}_{3}$ (compounds $\mathbf{1 1}-\mathbf{G}_{\mathbf{n}}$, Figure 7.2.a). In this case, the reactions were first carried out up to generation $5,{ }^{13}$ then up to generation $8,{ }^{15}$ which is presumably not the highest generation obtainable from this core.

\subsubsection{Different types of cores}

The method of synthesis shown in Figure 7.2.a is very robust, and can be easily modified, for instance by starting from different cores, which should have either $\mathrm{P}-\mathrm{Cl}$ or aldehyde functions. Several of these different cores were obtained by the selective modification of the cyclotriphosphazene, to have at least one function among six different from the others. Many different examples have been already proposed, as shown in Figure 7.2.b, and these compounds have been recently reviewed. ${ }^{16} \mathrm{~A}$ few examples can be particularly emphasized, such as the grafting of a single pyrene for interacting with graphene, and used for catalysis, ${ }^{17}$ a fluorescent derivative of julolidine for detecting cellular events, ${ }^{18}$ or a two-photon absorption (TPA) fluorophore linked to two cyclotriphosphazenes, used for bioimaging in vivo. ${ }^{19}$ Two, three and even up to five chlorine atoms of $\mathrm{N}_{3} \mathrm{P}_{3} \mathrm{Cl}_{6}$ can be selectively replaced by different phenols. ${ }^{20}$

However, many other types of cores can be used with such method of synthesis of dendrimers, provide they possess aldehyde functions, as shown in Figure 7.2.c. Among them, one can cite in particular an octaaldehyde phthalocyanine, for the detection of the internal behavior of the dendrimers, ${ }^{21,22}$ an ammonium trialdehyde for the delivery of carteolol (an anti-hypertensive ocular drug), ${ }^{23}$ and several compounds having two types of functions, such as an activated vinyl group and two aldehydes, for the synthesis of dendrons (dendritic wedges) and of diverse types of dendritic architectures. ${ }^{24}$ 
[Figure 7.2 near here]

\subsubsection{Different types of branches based on hydroxyaldehydes}

The easiest way to modify the types of branches consists in replacing 4-hydroxybenzaldehyde by other hydroxyaldehydes, in particular to have longer branches. The hydroxyaldehydes used include 4-hydroxy-3methoxycinnamaldehyde, ${ }^{25}$ azobenzene derivative, for which a trans-cis isomerization was observed upon irradiation, ${ }^{26}$ different ferrocene derivatives, ${ }^{27-29}$ and TPA fluorophores. ${ }^{30,31}$ The same process can be applied to compounds possessing two aldehydes, with the aim of multiplying more rapidly the number of terminal functions. The first example concerned the 5-hydroxyisophthaldehyde, ${ }^{32}$ and very recently a new hydroxydialdehyde based on trazine and piperazine was synthesized to build dendrimers up to the fourth generation in only four steps. ${ }^{33}$ (Figure 7.2.d)

\subsubsection{Different types of branches based on the Staudinger reaction}

Besides the condensation reaction between aldehydes and the phosphorhydrazide, another reaction has been found very useful for the synthesis of phosphorhydrazone dendrimers: the Staudinger reaction between phosphines and azides, in particular to create $\mathrm{P}=\mathrm{N}-\mathrm{P}=\mathrm{S}$ linkages, when using a thiophosphorus azide. This reaction is quantitative and generates $\mathrm{N}_{2}$ as single by-product, thus it is particularly attractive for the synthesis of dendrimers. $\mathrm{P}=\mathrm{N}$ functions are generally easily hydrolysed, but the presence of the $\mathrm{P}=\mathrm{S}$ group induces a larger better stability. The first series of phosphorus dendrimers including these linkages necessitated three steps to build one generation, starting from aldehyde groups: i) condensation of methylhydrazine, ii) reaction with $\mathrm{Ph}_{2} \mathrm{PCl}^{34}$ in basic conditions or with $\mathrm{Ph}_{2} \mathrm{PCH}_{2} \mathrm{OH},{ }^{35}$ and iii) Staudinger reaction between the phosphine end groups and an azido dialdehyde, to have again aldehydes as terminal groups. In both cases, the synthesis was carried out up to the third generation (compound 12-G. $\mathbf{3}$, Figure 7.3.a). It must be emphasized that the classical method shown in Figure 7.2.a can be applied from the aldehydes obtained in the third step of the method shown in Figure 7.3.a, thus both methods are fully compatible, and the $\mathrm{P}=\mathrm{N}-\mathrm{P}=\mathrm{S}$ linkage can be introduced either at one, several or all layers. Figure 7.3.b displays the synthesis of dendrimers possessing $\mathrm{P}=\mathrm{N}-\mathrm{P}=\mathrm{S}$ linkages at each generation, using a two-step

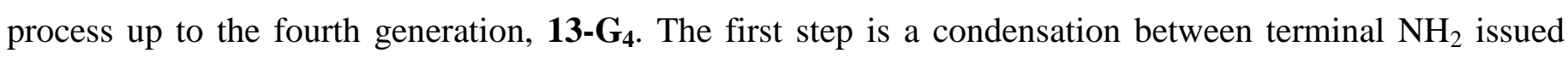
from methylhydrazine, and a phosphino aldehyde, whereas the second step is a Staudinger reaction between the phosphine and a phosphorus azide functionalized by two methylhydrazine groups. ${ }^{36}$

Taking profit of both quantitative reactions shown above, i.e. the condensation reaction of hydrazine (A) 
with aldehyde (D), and the Staudinger reaction of phosphine (B) with azide (C), we have designed several branched monomers including two of these functions, to synthesize dendrimers more rapidly: one reaction, one generation. First, we designed compounds $\mathrm{H}_{2} \mathrm{NNMeP}(\mathrm{S})\left(\mathrm{OC}_{6} \mathrm{H}_{4} \mathrm{PPh}_{2}\right)_{2}\left(\mathbf{A B}_{2}\right)$ and $\mathrm{N}_{3} \mathrm{P}(\mathrm{S})\left(\mathrm{OC}_{6} \mathrm{H}_{4} \mathrm{CHO}\right)_{2}$ $\left(\mathbf{C D}_{2}\right)$ (Figure 7.3.c). The synthesis was carried out step-wise up to the fourth generation of a layered dendrimer. The synthesis was also carried out in a one-pot but multi-step process, adding periodically strictly stoichiometric amounts of reagents. The purity of the fourth generation obtained in this one-pot

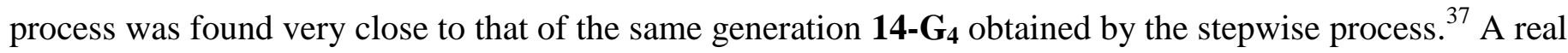
"Lego" chemistry was then developed using the same concept, from monomers $\mathbf{C A}_{\mathbf{2}}$ and $\mathbf{D} \mathbf{B}_{\mathbf{2}}$. The reaction was carried out up to the fourth generation, affording another type of phosphorus dendrimers, $\mathbf{1 5}-\mathbf{G}_{\mathbf{n}}$ functionalized by either $\mathrm{NH}_{2}$ or phosphines as terminal groups (Figure 7.3.d). ${ }^{38}$ The same concept was also extended to monomers having a larger number of functional groups, $\mathbf{A B}_{\mathbf{5}}$ and $\mathbf{C D}_{\mathbf{5}}$ monomers based on the specific reactivity of $\mathrm{N}_{3} \mathrm{P}_{3} \mathrm{Cl}_{6},{ }^{16}$ to multiply more rapidly the number of terminal groups. These highly branched monomers may induce rapidly problems of steric hindrance, thus they were used first in combination with the $\mathbf{A B}_{\mathbf{2}}$ and $\mathbf{C D}_{\mathbf{2}}$ monomers. For instance, $\mathbf{A B}_{\mathbf{2}}$ and $\mathbf{C D}_{\mathbf{5}}$ monomers were used to synthesize dendrimers up to the fourth generation. Another attempt was made using $\mathbf{A B}_{\mathbf{5}}$ and $\mathbf{C D}_{\mathbf{2}}$, but an important steric hindrance was expected and observed at the first generation. Indeed the condensation reaction was abnormally slow and needed 4 days at $100^{\circ} \mathrm{C}$ to go to completion, but the next steps occurred without any problem, and the synthesis was also carried out up to the fourth generation, having 60 aldehyde terminal groups in both cases. Finally, the synthesis using both $\mathbf{A B}_{\mathbf{5}}$ and $\mathbf{C D}_{\mathbf{5}}$ monomers was attempted. Each step needed several days to go to completion, thus the synthesis was stopped at the third generation 16$\mathbf{G}_{3}$, which has 750 phosphine terminal functions after only three reactions (Figure 7.3.e). ${ }^{39}$ In view of the long time needed to get the third generation, no attempt was made to try to synthesize the next generation.

All the previous examples concern dendrimers built using Staudinger reactions in combination with condensation reactions, but we have also synthesized dendrimers, using only the Staudinger reaction and a single monomer, an azido diphosphine complexed by $\mathrm{BH}_{3}$. The azide was reacted in the first step with a triphosphine core, then the terminal phosphine complexes were deprotected with DABCO $(1,4-$ diazabicyclo[2.2.2] octane). The next generation was obtained by using the same monomer, followed by its deprotection. These reactions were carried out up to generation 5 (17-G $\mathbf{-}$ in Figure 7.3.f), for which the polydispersity was very low (1.029). Hyperbranched polymers were also synthesized in only one step by using the deprotection of the monomer, but the polydispersity was very high for these polymers, from 1.5 to 8 , depending on the samples, and the properties, in particular the intrinsic viscosity was very different compared to that of the corresponding dendrimers. ${ }^{40}$ 
[Figure 7.3 near here]

\subsubsection{Reactivity inside the structure and special dendritic architectures}

The presence of $\mathrm{P}=\mathrm{N}-\mathrm{P}=\mathrm{S}$ linkages inside dendrimers is particularly useful for obtaining original types of dendritic structures. Indeed, these linkages are easily and specifically alkylated on sulphur with alkyl triflates, ${ }^{35}$ eventually functionalized, ${ }^{41}$ because they have a mesomeric form in which a negative charge is located on sulphur $\left({ }^{+} \mathrm{P}-\mathrm{N}=\mathrm{P}-\mathrm{S}^{-}\right)$. Other $\mathrm{P}=\mathrm{S}$ groups in the dendrimers (not included in $\mathrm{P}=\mathrm{N}-\mathrm{P}=\mathrm{S}$ ) are not alkylated. An example is shown in Figure 7.4.a, compound $\mathbf{1 8}^{\mathbf{\prime}} \mathbf{-} \mathbf{G}_{\mathbf{3}}$. The alkylation on sulphur induces a weakening of the phosphorus sulphur bond, which is easily cleaved using a nucleophilic phosphine such as $\mathrm{P}\left(\mathrm{NMe}_{2}\right)_{3}$, to generated tricoordinated phosphorus atoms $\left(\mathrm{P}^{\mathrm{III}}\right)$ inside the structure, such as compound 18'$\mathbf{G}_{3}$. These $\mathrm{P}^{\mathrm{III}}$ have been used to react with various functionalized azides, having primary amines,

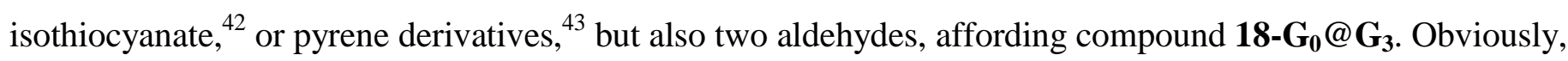
many reactions were performed from these internal aldehydes, but the most interesting is the step-by-step growing of new branches inside the dendrimer, affording 18-G $\mathbf{G}_{\mathbf{1}} @ \mathbf{G}_{\mathbf{3}}, \mathbf{1 8}-\mathbf{G}_{\mathbf{2}} @ \mathbf{G}_{\mathbf{3}}$, and finally 18-G $\mathbf{G}_{\mathbf{3}} @ \mathbf{G}_{\mathbf{3}}$, possessing 96 aldehydes and 48 phenoxy terminal groups. ${ }^{44}$ The three-step method shown in Figure 7.3.a was also applied to compound $\mathbf{1 8}-\mathbf{G}_{\mathbf{0}} @ \mathbf{G}_{3}$, to grow new branches including P=N-P=S linkages, which were complexed by gold. ${ }^{45}$ In an alternative way, starting from compound 18-G $\mathbf{G}_{\mathbf{0}} @ \mathbf{G}_{\mathbf{3}}$, dendrons bearing a primary hydrazine at the core were grafted, to afford new internal branches in one step, instead of the multistep procedure shown in Figure 7.4.a. These condensation reactions were slow and necessitated 10 days to go to completion. Only the $2^{\text {nd }}$ generation dendron could be grafted, not the $3^{\text {rd }}$ one, ${ }^{46}$ whereas the $3^{\text {rd }}$ generation was previously obtained step-by-step.

Many different dendritic structures were built using phosphorus-containing dendrons, in particular those having a $\mathrm{CH}_{2}=\mathrm{CH}-\mathrm{P}=\mathrm{N}-\mathrm{P}=\mathrm{S}$ linkage at the core. Indeed, the presence of the $\mathrm{P}=\mathrm{N}-\mathrm{P}=\mathrm{S}$ group induces an activation of the vinyl group, which is able to react in Michael-type additions with different amines, preferably diamines, and hydrazines, to afford a $\mathrm{NH}_{2}$ group at the core. Such function was mainly used for condensation reactions with an aldehyde, for peptide-type coupling, ${ }^{47}$ but also for the condensation with two equivalents of $\mathrm{Ph}_{2} \mathrm{PCH}_{2} \mathrm{OH}$, followed by Staudinger reactions. These reactions were applied for the synthesis of a kind of layered segment-block dendritic compound having a non-symmetrical internal structure, despite the presence of 576 identical dimethylamino groups end groups, or another unsymmetrical dendritic species possessing $16 \mathrm{NMe}_{2}$ and 64 nitrile terminal groups (Figure 7.4.b). ${ }^{24}$ The Michael-type addition was applied also to dendrons functionalized by tertiary amines as terminal groups together with dendrons having carboxylates as terminal groups. Such association was performed with dendrons of the same generation, but 
also with dendrons of different generations, to synthesize unsymmetrical bis-dendrons, also called "Janus" dendrimers, ${ }^{48}$ as shown in Figure 7.4.c. The amino groups of the bis dendrons could be alkylated with MeI to afford ammoniums on one side and carboxylates on the other side. ${ }^{49}$

[Figure 7.4 near here]

Other types of reactions have been used for synthesizing phosphorus-containing dendrimers, but these reactions were carried out only up to low generations $\left(\mathrm{G}_{1}\right.$ or $\left.\mathrm{G}_{2}\right)$. Such reactions include the "click" reaction between alkynes and azides, affording dendrimers incorporating triazole units at each generation, ${ }^{50}$ and also the alkylation of $4,4^{6}$-bypyridine, to afford phosphorus dendrimers incorporating viologen units in their structure. ${ }^{51}$ The diversity of the reactions usable for synthesizing phosphorus dendrimers has been illustrated recently with the synthesis of "onion peel" ${ }^{152}$ dendritic structures, as illustrated in Figure 7.4.d, by a compound possessing 7 different layers of phosphorus atoms. ${ }^{53}$

\subsubsection{Non-exhaustive overview of the types of terminal functions}

During the course of the synthesis of the phosphorhydrazone dendrimers, the terminal functions are either aldehyde or $\mathrm{P}(\mathrm{S}) \mathrm{Cl}_{2}$ groups, depending on the step considered. Both display a versatile reactivity, which has led to the grafting of an enormous number of diversified terminal functions. In most cases, the aldehydes are used mainly for condensation reactions, but also for Wittig reactions, whereas the $\mathrm{P}(\mathrm{S}) \mathrm{Cl}_{2}$ groups are used for substitution reactions, generally with phenols, but also with amines. A large but not exhaustive list of terminal functions already grafted to phosphorhydrazone dendrimers is shown in Figure 7.5. The largest number of functions has been obtained by reaction of phenols on the $\mathrm{P}(\mathrm{S}) \mathrm{Cl}_{2}$ terminal groups. Some series can be emphasized, in particular the use of tyramine $\left(\mathrm{HOC}_{6} \mathrm{H}_{4} \mathrm{CH}_{2} \mathrm{CH}_{2} \mathrm{NH}_{2}\right)$, through the functionalization of the $\mathrm{NH}_{2}$ group, generally before the grafting to the dendrimer. Various types of phosphines ${ }^{54,55}$ and pyridine-imine ligands, ${ }^{31,56,57}$ all of them used subsequently for the complexation of diverse metal derivatives, phosphonates ${ }^{58-62}$ and carboxylates, ${ }^{63,64}$ carbohydrates ${ }^{65}$ and fluorescent derivatives ${ }^{47,66-69}$ have been grafted in this way. Other series concern diverse ferrocene derivatives, ${ }^{27,28,70-73}$ triazole derivatives obtained by "click" reactions, ${ }^{50,74,75}$ piperazine derivatives, ${ }^{76-78}$ and long chains. ${ }^{79,80}$ Other phenol phosphines, ${ }^{17,40,81,82}$ phenol ligands, ${ }^{83-85}$ phenol fluorophores, ${ }^{86,87}$ and miscellaneous phenol derivatives 24,50,88-94 have been also reacted with the $\mathrm{P}(\mathrm{S}) \mathrm{Cl}_{2}$ terminal groups (Figure 7.5.a). Primary amines also react easily with the $\mathrm{P}(\mathrm{S}) \mathrm{Cl}_{2}$ terminal functions. The first example was with allylamine, ${ }^{95}$ but the most important one concerns N,N-diethylethylenediamine, in which the tertiary amine is easily protonated or alkylated, ${ }^{96}$ inducing the solubility of the dendrimers in water. ${ }^{97-98}$ A series of other diamines has also been used, ${ }^{99}$ as 
well as tetraazamacrocycles, providing either 5- or 6-membered rings including one phosphorus and two nitrogen atoms ${ }^{100}$ (Figure 7.5.b).

The aldehyde terminal functions have been primarily used for condensation reactions with amines such as an amino crown ether ${ }^{95}$ chiral methylbenzyl amine,${ }^{101}$ a chiral aminophosphine, ${ }^{102}$ aminopyrene,${ }^{103}$ fipronil, ${ }^{104}$ TEMPO derivatives, ${ }^{105,106}$ or triazamacrocycles. ${ }^{107-109}$ As the imine functions are generally not stable towards water, in most cases they have been reduced, using either $\mathrm{BH}_{3}$ or $\mathrm{NaBH}_{4}$. Addition on the imine bond of compounds having a P-H bond has been also performed, to graft phosphonates. ${ }^{59,110-112}$ Different hydrazines have also been condensed with aldehydes. In these cases, the $\mathrm{C}=\mathrm{N}$ function is stable and it is not necessary to reduce it. Fluorene, ${ }^{95}$ Girard P and T reagents, ${ }^{113-115}$ and pyridine ${ }^{56,57}$ derivatives have been grafted in this way. However the condensation of hydrazine (used in large excess) and of methylhydrazine are particularly interesting, as they afford a $\mathrm{NH}_{2}$ or $\mathrm{NH}$ terminal function, ${ }^{13,116}$ both suitable for other reactions, such as the grafting of phosphines from $\mathrm{Ph}_{2} \mathrm{PCH}_{2} \mathrm{OH},{ }^{117-119}$ the opening of $\gamma$-thiobutyrolactone affording thiols as terminal functions, ${ }^{120,121}$ or the condensation with aldehydes bearing a phosphine, a phosphate or even a phosphorus ylide. ${ }^{110}$ Another well-known reaction of aldehydes is the Wittig reaction with phosphorus ylides. It has been performed several times on the surface of dendrimers, first for the grafting of a nitrile or COMe, ${ }^{95}$ then of diverse esters, thioamides and phosphonates, ${ }^{122}$ and also of tetrathiafulvalene derivatives, ${ }^{123}$ and bithiophene. ${ }^{124}$ Addition reactions on aldehydes have been performed with phosphonates, ${ }^{110,112}$ and with a phosphino zirconaindene. ${ }^{125}$ An interesting reaction is the reduction of the aldehyde to benzyl alcohol. ${ }^{126}$ Indeed the alcohol can be used in couplings with carboxylic acids. ${ }^{127}$ It can be also modified to benzyl chloride, ${ }^{50}$ suitable for the alkylation of amines, ${ }^{128}$ and to benzyl azide. ${ }^{50}$ Another reaction from aldehydes concern a Doebner-like procedure for obtaining carboxylic acid terminal functions, ${ }^{126,129,130}$ (Figure 7.5.c).

A very original property of dendrimers terminated with $\mathrm{P}(\mathrm{S}) \mathrm{Cl}_{2}$ functions is the possibility to react independently and specifically each $\mathrm{Cl}$. This sequence of reactions has been carried out essentially with amines. The first example concerned the reaction of allyl or diallyl amine, followed by the reaction of propargylamine. ${ }^{131}$ The same concept has been applied recently for the synthesis of dendrimers having both a primary amine and a triethoxysilyl group on each $\mathrm{P}(\mathrm{S})$ terminal functions. ${ }^{132}$ Other possibilities to have two different amines on each $\mathrm{P}(\mathrm{S})$ group concern the use of a non-symmetrical diamine, for instance bearing a macrocycle on one side, ${ }^{133}$ or starting from a fully substituted dendrimer with allylamine, reaction of $\mathrm{Ph}_{2} \mathrm{PCH}_{2} \mathrm{OH}$ with only one allylamine. ${ }^{134}$ The same approach was attempted with phenols instead of amines. The selectivity was less good than with amines, but a selectivity of $95 \%$ could be obtained, leading to dendrimers bearing both ethacrynic acid derivatives and either aldehyde or phosphonate terminal functions 
(Figure 7.5.d). ${ }^{135}$

[Figure 7.5 near here]

\subsubsection{Selected properties and uses of phosphorus dendrimers}

Most of the large number of terminal functions displayed in Figure 7.5 have been linked to phosphorhydrazone dendrimers for specific purposes and uses, mainly for catalysis, for the elaboration or modification of materials at the nanometric scale, or for biology/nanomedicine. These three domains will be displayed below.

\subsubsection{Phosphorus dendrimers for catalysis}

The first attempt in catalysis with phosphorhydrazone dendrimers concerned diphosphine terminal functions complexing palladium for the catalysis of Stille couplings, or complexing ruthenium for the catalysis of Knoevenagel condensations and diastereoselective Michael additions. ${ }^{119}$ Since then, many other examples have been studied, ${ }^{54,71,72,81,102,128,136,137}$ and the field has been reviewed recently, ${ }^{138}$ thus only the most important and recent examples will be described here. One of the main reason for using dendrimers in catalysis is the expectation to observe a "dendritic effect", ${ }^{139}$ i.e. an increase of the catalytic efficiency when the generation increases, of course considering the same number of catalytic sites in comparative experiments. A series of dendrimers ended by pyridine-imine ligands complexing copper (I) has been used for catalyzing $\mathrm{N}$-arylations. When using bromobenzene as arylation agent, the monomeric complex is non active, whereas the dendrimers have an increased efficiency when the generation increases, demonstrating a true dendritic effect on the yield. ${ }^{83}$ The field of chiral dendritic catalysts has been reviewed. ${ }^{140}$ The most important contribution of phosphorhydrazone dendrimers to this field concerns dendritic phosphoramidite ligands applied to Rh-catalyzed [2+2+2] cycloaddition reactions. The monomeric complex induced no enantiomeric excess, whereas all the generations of the dendrimers, from $\mathrm{G}_{1}$ to $\mathrm{G}_{3}$ afforded very high $e e$, even after recovery and reuse ( 95 to $98 \% e e$ ), for the synthesis of axially chiral biaryl compounds. ${ }^{82} \mathrm{~A}$ recent original example concerns the possibility to switch ON-OFF-ON the efficiency of the dendritic catalysts. For this purpose, a phosphino ferrocene dendrimer has been complexed with ruthenium, for catalyzing the isomerization of an allylic alcohol to ketone. If the ferrocene is oxidized to ferrocenium, the catalytic efficiency drops dramatically, whereas the catalytic efficiency is recovered when reducing the ferrocenium to ferrocene. This is the very first example of a catalytic switch using a dendrimer. ${ }^{73}$ 
To contribute to the field of "green chemistry" benign metals have been used, and in particular copper, as illustrated above. ${ }^{83}$ Other examples concern azabisoxazoline ligands complexing copper on the surface of phosphorus dendrimers, and used for catalyzing asymmetric benzoylation reactions, ${ }^{74}$ and copper complexes of diketones, used for O-arylations of 3,5-dimethylphenol by arylbromides. ${ }^{84}$ An important property of dendritic catalysts is the possibility to recycle and reuse them several times, due to their large size, generally larger than that of the reagents and products. The recycling by precipitation with a poor solvent, in particular diethylether for phosphorhydrazone dendrimers, can be very efficient, as illustrated by dendritic terpyridine terminal functions complexing scandium triflate, used for catalyzing Friedel-Crafts acylations of aromatics. Indeed, this dendrimer could be recovered and reused 12 times, even by changing the substrates at each run. ${ }^{85}$ Another example of a very efficient recovery concerned a small unsymmetrical dendrimer having a pyrene linked to the core and phosphines complexing palladium acetate as terminal functions, which was used for catalyzing Suzuki couplings of boronic acids with arylbromides. The pyrene was used to interact at room temperature with the graphene layer covering cobalt nanoparticles. When heating, the dendrimers went in solution to perform catalysis, and came back to the surface of cobalt nanoparticles when cooling after the catalysis. As cobalt nanoparticles are magnetic, the combination of the dendrimers and the nanoparticles could be recovered and reused very easily and very cleanly. The dendrimer could be recovered and reused 12 times for the synthesis of the anti-inflammatory drug felbinac, obtained in $100 \%$ yield, even at the twelfth run. ${ }^{17}$ The loss of metal (leaching) is a major problem of catalysis with metal derivatives, and dendrimers could afford a solution to this problem. Indeed, in another example of Suzuki coupling, the influence of triphenylphosphine and thiazolyldiphenyl phosphine ligands both complexing palladium on the surface of dendrimers and of the corresponding monomers, on the leaching of Pd, was measured. For both monomers the leaching was very high, whereas it was reduced with both first generation dendrimers. The leaching is $173 \mathrm{ppm}$ in the case of the dendritic triphenyl phosphine, whereas it is undetectable in the case of the dendritic thiazolyl phosphine. ${ }^{55}$ Another way to avoid metal leaching consists in using organocatalysts (no metal). ${ }^{141}$ (S)- $\alpha, \alpha$-diphenylprolinol trimethylsilyl ether (Jørgensen-Hayashi catalyst) grafted onto phosphorus dendrimers and on graphene coated magnetic cobalt nanoparticles was used for catalyzing Michael additions of a wide range of aldehydes to different nitroolefins. The dendrimer of third generation could be recovered and reused in 7 consecutive runs without loss of activity, contrarily to the nanoparticles, for which the activity significantly decreased from the $3^{\text {rd }}$ run. ${ }^{75}$ Dendrimers decorated on their surface with (+)-cinchonine moieties were used as organocatalysts for the $\alpha$-amination of several $\beta$-dicarbonyl compounds. The first-generation dendrimer showed the highest activity and enantioselectivity, and it was recovered and reused over 10 cycles without loss of activity. ${ }^{92}(+)$-Cinchoninium salts were obtained on the surface of phosphorhydrazone dendrimers by the quaternisation of the quinuclidinic $\mathrm{N}$ atom. These compounds were used as catalysts for the asymmetric alkylation of a glycinate Schiff base with benzyl 
bromide. The catalysts were recovered and reused for five consecutive runs without loss of activity and with only a slight decrease in enantioselectivity. ${ }^{93}$

\subsubsection{Phosphorus dendrimers for nanomaterials}

The very first examples of phosphorus dendrimers in the field of materials concerned the synthesis of hybrid materials incorporating phosphorus dendrons in nanoporous silica through a sol-gel process, ${ }^{142}$ and first generation phosphorus dendrimers used as spacer of titanium oxo clusters. ${ }^{126}$ The early times of the field have been reviewed, ${ }^{143,144}$ thus only the recent important examples will be given here. Five different types of uses of phosphorus dendrimers in the field of materials can be distinguished: $i$ ) nano-objects and materials constituted exclusively of dendrimers; ii) nanoparticles elaborated thanks to dendrimers, or protected by dendrimers; iii) interaction of dendrimers with materials for trapping pollutants; $i v$ ) supports modified by dendrimers for cells culture; and $v$ ) sensors obtained by modifying solid surfaces by dendrimers. These five different uses will be presented in this order.

The latest example of materials constituted exclusively of dendrimers concerns dendrimers functionalized by triaza macrocycles bearing long alkyl chains, which display liquid crystal properties, forming columnar phases, even with the fourth generation. ${ }^{109}$ However, the largest number of materials exclusively composed of dendrimers were elaborated by electrostatic templating strategies, ${ }^{145}$ using step-by-step positively and negatively charged dendrimers, bearing ammonium and carboxylate terminal functions, respectively. The first template used was a nanoporous alumina template. The possibility to deposit successively layer-bylayer charged dendrimers depends on the size of the holes of the template. With holes of $400 \mathrm{~nm}$, twenty bilayers of positively and negatively charged dendrimers of generation 4 could be deposited. Importantly, the alumina template could be destroyed using a strong base $(\mathrm{KOH})$, a strong acid $\left(\mathrm{H}_{3} \mathrm{PO}_{4}\right)$ and a strong oxidant $\left(\mathrm{CrO}_{3}\right)$, without destroying the layers of dendrimers, thus generating original nanotubes ${ }^{146}$ exclusively composed of dendrimers, with an external diameter of $400 \mathrm{~nm}$ (as the template), an inner diameter of $300 \mathrm{~nm}$, and a length of $80 \mu \mathrm{m}$, corresponding to the depth of the holes of the template. ${ }^{147}$ In a similar approach, negatively charged quantum dots were used at some layers instead of the negatively charged dendrimers. Three different types of quantum dots, composed of different ratios of $\mathrm{Zn}, \mathrm{Cd}$ and $\mathrm{Se}$, with emission at 561, 594, and $614 \mathrm{~nm}$, respectively, were introduced in order to induce a graded band gap, ${ }^{148}$ which has been used ultimately for the sensitive detection of DNA hybridization. ${ }^{149}$ When the diameter of the pore decreases, the penetration of the dendrimers inside the pore can be decreased and even forbidden, in particular if the ionic strength is increased, even if the diameter of the pores is by far larger than that of the dendrimers. ${ }^{150}$ The same layer-by-layer deposit has been carried out on the surface of 
microspheres composed of melamine formaldehyde, using either poly(styrenesulfonate) and positively charged dendrimers, or poly(allylamine hydrochloride) and negatively charged dendrimers. Removal of the microsphere using $\mathrm{HCl}$ generates microcapsules, which are often opened when only 4 bilayers are used, but closed with five bilayers. ${ }^{151}$ Stiffening of these capsules has been observed in the presence of THF. ${ }^{152}$ DNA has been used in the same conditions, instead of the negatively charged polymer. ${ }^{153}$ It has been possible also to deposit single stranded DNA on the surface of the microsphere, which becomes the interior of the microcapsule after destruction of the microsphere. In the presence of a fluorescent single stranded DNA, a different behaviour was observed depending on the complementarity or not of the DNAs. The complementary oligonucleotides go inside the microcapsule, thus the fluorescence is observed inside the microcapsules, whereas the non-complementary oligonucleotides stay in the wall of the microcapsule, and thus the fluorescence is observed only in the wall. ${ }^{154,155}$

Diverse types of metallic nanoparticles have been obtained thanks to diverse phosphorus dendrimers used as templates. The first example concerned dendrimers functionalized by thiols, used to interact with the gold cluster $\mathrm{Au}_{55}\left(\mathrm{PPh}_{3}\right)_{12} \mathrm{Cl}_{6}$. This interaction induces the peeling of the ligands, to generate naked $\mathrm{Au}_{55}$, which associated in nanocrystals of $\mathrm{Au}_{55}$, wrapped and stabilized by the dendrimers. ${ }^{120}$ The same process was carried out with the same dendrimers deposited as a monolayer on a silicon wafer. ${ }^{121}$ Dendrimers decorated with triazatriolefinic macrocycles were also used to generate nanoparticles. Indeed, the reaction of these dendrimers with $\mathrm{Pd}^{0}\left(\mathrm{Pd}_{(} \mathrm{PPh}_{3}\right)_{4}$ or $\mathrm{Pd}_{2}(\mathrm{dba})_{4}$, with dba = dibenzylidene acetone) led to the obtaining of $\mathrm{Pd}^{0}$ nanoparticles, which were found efficient and recyclable for catalyzing Mizoroki-Heck couplings of iodobenzene with n-butylacrylate. ${ }^{107}$ Analogous dendrimers afforded a network of $\mathrm{Pt}^{0}$ nanoparticles, when using $\mathrm{Pt}_{2}(\mathrm{dba})_{3}$. Interestingly, these Pt nanoparticles are organized in "dendritic" networks, for which the length of the branches increases when the generation of the dendrimer increases. ${ }^{108,133}$ Generation 4 of dendrimers ended with either phosphonates, ${ }^{156}$ ammoniums, or diketones have been used for the synthesis of discrete anatase nanocrystals (ordered $\mathrm{TiO}_{2}$ ) at low temperature, and prevent the classical anatase $\rightarrow$ rutile phase transformation up to $800^{\circ} \mathrm{C}^{157}$ Silver nanoparticles have been generated with dendrimers that have been grafted first on silica nanoparticles, then the terminal functions have been modified to phosphonates with lateral poly(ethyleneglycol) (PEG) chains. Addition of silver acetate to these materials induced the formation of silver and silver oxide nanoparticles, which exhibit antibacterial activity. ${ }^{158}$ All the abovementioned syntheses of nanoparticles are carried out in solution, but an example has been recently obtained solventless, by milling under air $\mathrm{RuCl}_{3}, \mathrm{NaBH}_{4}$ and a polyphosphorhydrazone dendrons (generations 0 to 2) having an alkyl chain at the focal point and triarylphosphines on the surface. The resulting Ru nanoparticles have a diameter in the 2-3 $\mathrm{nm}$ range, they are stable upon storage in solution or as powders, and they can efficiently catalyze the hydrogenation of styrene. ${ }^{137}$ The surface of diverse types of nanoparticles has been 
modified with dendrimers, for several purposes. In the first example, the grafting of cationic dendrons onto polystyrene nanoparticles prevent the aggregation of the nanoparticles, and induced the formation of stable, rigid and translucent hydrogels. ${ }^{115}$ The surface of magnetic cobalt nanoparticles covered by graphene was non-covalently modified with a dendron having a pyrene at the core, and palladium phosphine complexes as terminal functions. This system was successfully used for catalyzing the coupling of boronic acids with aryl bromide. The recovery of this system was easily carried out using a magnet, and it could be reused up to 12 times with a similar efficiency. ${ }^{17}$

Two recent examples concern the interaction of dendrimers with materials for trapping pollutants. Diverse types of bifunctional dendritic structures, ${ }^{132}$ bearing one or several triethoxysilane groups for the grafting to nanoporous silica, and primary amines have been tested for trapping $\mathrm{CO}_{2}$; the most efficient dendritic compound was a second generation dendron. ${ }^{159}$ The second example concerns a first generation dendrimer ended with ammonium groups, which was used for the intercalation inside different types of clays. The second generation induced an exfoliation of the clay, and not an intercalation. These modified clays have been used for trapping aqueous pollutants, in particular chromate ${ }^{160}$ and methylene blue. ${ }^{161}$

Two examples with a different outcome concern the modification of surfaces by dendrimers, to be used for the culture of cells. The layer-by-layer process was applied to negatively charged (carboxylates) and positively charged (ammoniums) generation 4 dendrimers. It was shown that foetal cortical rat neurons attached preferentially and matured slightly faster on surfaces terminated with positively charged dendrimers. ${ }^{162}$ In a second example, a single layer of bifunctional dendrimers was covalently grafted to a gold surface. Contrarily to the previous case, it was shown that human osteoblast cells adhere and proliferate well on negatively charged dendrimers, whereas cell apoptosis was observed on positively charged dendrimers. ${ }^{163}$

Sensor are the most important area concerning the use of phosphorus dendrimers in the field of materials. ${ }^{164}$ The first example concerned the electrochemical detection of barium, using an electrode modified by a dendrimer functionalized by tetrahydrothiophene-crown ether derivatives as terminal functions. ${ }^{123} \mathrm{~A}$ dendron bearing both phosphonate (for the grafting to a mesoporous titania film) and maleimide fluorescent entities afforded a hybrid material which was brightly fluorescent. The fluorescence was quenched in the contact with phenols, thus affording in particular a sensitive sensor for hazardous nitrophenols. ${ }^{67}$ Thick layers of dendrimers with aldehyde terminal functions, from generations 1 to 9 , deposited on a quartz crystal microbalance sensor, were used for the detection of 30 different vapors of solvents. The dendrimers have a different selectivity for different homologous series of guests, depending on the generation. ${ }^{165}$ The last 
example of detection of chemical entities was afforded by a multilayer film constituted of anionic gold nanoparticles and cationic dendrimers, obtained by layer-by-layer deposit, from which the dendrimers were removed using deep UV irradiation. The resulting multilayer of gold nanoparticles was used for the detection of five solvents with different refractive indices. ${ }^{166}$ Different types of biosensors, based on the hybridization of complementary single stranded DNA, have been elaborated using phosphorus dendrimers. Gold coated glass surfaces, functionalized with mercaptopropionic acid, were then used for the layer-bylayer deposit of positively and negatively charged dendrimers. On the last layer negatively charged, a high loading of probe DNA was covalently grafted. The hybridization with Cy5-labelled complementary target DNA was detected by surface plasmon field-enhanced fluorescence spectroscopy (SPFS), with a limit of detection at $510^{-11} \mathrm{M}$ and $310^{-11} \mathrm{M}$ on 1 bilayer and 4 bilayers of dendrimers, respectively. ${ }^{167}$ Another example of electrostatic interactions used for the sensitive detection of DNA hybridization was constituted by a layer of a positively charged phosphorus dendrimer, and a layer of perylene diimide star polymer negatively charged, to which probe DNA was covalently grafted. The hybridization with complementary target DNA was also detected by SPFS, with an ultra-sensitivity of $10^{-18} \mathrm{M}^{168}$ Aldehyde dendrimers were used for the functionalization of AFM tip, for the immobilization of the GST (glutathione S-transferase) antibody, and for probing single molecule force interaction with the GST. ${ }^{169}$ The covalent grafting of the same aldehyde dendrimers to glass slides functionalized by aminopropyl triethoxysilane, followed by the attachment of probe DNA afforded dendri-chips, which were able to detect the hybridization with Cy5labelled complementary target DNA with a limit of sensitivity at $10^{-12} \mathrm{M} \cdot{ }^{170}$ These slides are very stable, can be re-used at least ten times, and are able to detect a mutation in the middle of the sequence of the complementary oligonucleotide. ${ }^{171}$ The same concept was developed on a piezoelectric membrane, for detecting streptavidin-gold nanoparticles interaction with biotinylated DNA, ${ }^{172}$ and for microstructured liposome arrays. ${ }^{173}$ Recent developments of these dendri-chips concern the creation of a start-up (Dendris), which created in particular chips for the diagnosis of respiratory diseases. ${ }^{174}$

\subsubsection{Phosphorus dendrimers for biology/nanomedicine}

This field becomes more and more important, and has been reviewed very recently. ${ }^{175}$ Three different types of phosphorus dendrimers can be considered: $i$ ) polycationic dendrimers with $\mathrm{N}, \mathrm{N}$-diethylethylene diamine salt as terminal functions, essentially of generation 4 , used both for the delivery of biological entities and as drug per se; ii) neutral dendrimers, with different types of terminal functions (ligands, carbohydrates, PEGs, etc.), mainly tested as anti-cancer agents; and iii) polyanionic dendrimers, with either carboxylate terminal functions for drug delivery, or azabisphosphonate terminal functions as anti-inflammatory agent. The biological properties of phosphorus dendrimers will be described in this order, depending on the nature of 
their terminal functions.

The very first example of phosphorus dendrimers in the field of biology concerned polycationic dendrimers used as transfection agents for the delivery of the plasmid of luciferase into mammalian cells. The fourth generation was found the most efficient. ${ }^{96}$ It was used successfully later on for the delivery of the fluorescent probe 8-anilino-1-naphthalenesulfonate, of the anticancer drug cisplatin, and of the plasmid of the green fluorescent protein p-GFP. ${ }^{176}$ A fluorescent analogue of the second generation was used for studying its interaction with DNA, ${ }^{177}$ whereas the fluorescent octafunctional phthalocyanine cored-dendrimer was used for transfection experiments of a fluorescent oligonucleotide and of p-GFP. ${ }^{178}$ Transfection experiments were extended to the delivery of genes against HIV-1. In view of gene silencing, antisense phosphorothioate oligodeoxynucleotides and small interfering RNA (siRNA) were delivered into peripheral blood mononuclear cells (PBMC), and efficiently inhibited HIV-1 replication. ${ }^{179}$ The delivery of HIV-based peptides was also carried out, in view of HIV-1 vaccine development. ${ }^{180}$ The fourth generation of phosphorus dendrimers with $\mathrm{NHEt}_{2}{ }^{+}$terminal groups and of PAMAM dendrimer with $\mathrm{NH}_{3}{ }^{+}$terminal groups were used as carriers for transfecting Schwann cells with the aim of improving functional recovery of injured peripheral nerves of the hind limb of rats. ${ }^{181}$ The same positively charged dendrimer was also found to be a drug by it-self (drug per se). Indeed, it is able to interact with the scrapie form of different types of prions, responsible for several types of transmissible spongiform encephalopathy diseases, including the "mad cow" disease. This dendrimer prevents in vitro the transmission of the disease, and was also efficient in vivo with mice. ${ }^{182}$ It was shown that the same dendrimer is able to interfere with the aggregation process of peptides of prions by both slowing down the formation of aggregates, and by lowering the final amount of amyloid fibrils, a common hallmark of conformational diseases. The interaction of this dendrimer with heparin is directly responsible for the inhibition of fibril formation. ${ }^{183}$ The interaction of this dendrimer with peptide PrP 185-208, ${ }^{184}$ which has a domain structurally analogous to that of peptides involved in Alzheimer's disease, and PrP 106-126 which is suspected to be preferentially involved in spongiform encephalopathies ${ }^{185}$ has been also assessed. Cationic phosphorus dendrimers of generations 3 and 4 are also able to affect $\beta$-amyloid (A $\beta(1-28)$ peptide) and MAP-Tau aggregation processes, to inhibit acetylcholinesterase activity, to decrease the secretion of TNF- $\alpha$, and they have weak antioxidant effects. ${ }^{97,98}$ The same dendrimers were used for decreasing the fibrillation of $\alpha$-synuclein, as a potential therapeutic strategy for neurodegenerative disorders such as Parkinson's disease. ${ }^{186}$ Several positively charged dendrimers can prevent damage to embryonic mouse hippocampal cells (mHippoE-18) caused by rotenone, which is a pesticide. ${ }^{187}$

Several types of phosphorus dendrimers bearing neutral terminal functions have shown anti-cancer 
properties. Generations 0 of viologen dendrimers with either ethylphosphonate or short PEG terminal functions were found non-toxic towards a normal cell line (B14 fibroblasts), but toxic towards the cancer cell line N2a. ${ }^{188}$ Several generations of dendrimers bearing as terminal functions diverse types of ethacrynic acid derivatives, which is a weak inhibitor of glutathione-S-transferase P1-1, overexpressed in a variety of cancer cells, were synthesised. Several of these dendrimers display strong anti-proliferative activities towards solid and liquid tumours, illustrating the effectiveness of the dendritic effect. ${ }^{77,78}$ Various types of pyridine-imine dendritic copper complexes (and also their non-complexed analogues) have been synthesized and characterized, ${ }^{57}$ then screened for anti-proliferative activity against several human cancer cell lines, with $\mathrm{IC}_{50}$ values ranging 0.3-1.6 $\mu \mathrm{M} .{ }^{56}$ Cell death pathways have been examined in human cancer cell lines, showing that early apoptosis was followed by secondary necrosis, and the detailed mechanism of action of these dendrimers has been elucidated. ${ }^{31}$ A family of neutral dendrimers (generations 1 to 4 ) capped with 1, 2 , or 3 mannose derivatives was synthesised with the aim of discovering new anti-inflammatory drugs against acute inflammatory diseases. After different biological tests, the third generation capped with trimannosides was selected, and administered per os to mice model of acute lung inflammation, inducing a significant reduction of lung inflammation. ${ }^{65}$

Negatively charged dendrimers have been obtained by grafting as terminal functions either carboxylates, for drug delivery, or phosphonates as drugs per se. The interaction of phosphorus dendrimers ended by carboxylic acid functions with N-hexadecylamino-1-deoxylactitol affords "catanionic" (cationic and anionic) dendrimers, ${ }^{129}$ which are multivalent chimera of galactosylceramide (galcer), a cellular receptor involved in the early step of HIV infection. These dendrimers have HIV-1 inhibition activity in the submicromolar range in vitro. ${ }^{130}$ Analogous experiments were carried out with dendrimers ended by phosphonic acids instead of carboxylic acid. ${ }^{60,61}$ The same concept was applied to another negatively charged (carboxylates) phosphorus dendrimer, for the delivery of carteolol, an ocular anti-hypertensive drug against glaucoma, and was successfully tested in the eyes of rabbits. ${ }^{23}$ A first generation dendrimer bearing negatively charged azabisphosphonate terminal functions was found able to multiply by up to 500 after 3 weeks in culture the number of Natural Killer (NK) cells, a population of innate immunity, which plays a key role in anti-cancer immunity. These NK cells obtained in the presence of the dendrimer are fully functional, and able to kill their normal targets, in particular various leukaemia and carcinoma cell lines. ${ }^{59,189}$ Multiplication of NK cells in the presence of the dendrimer was carried out not only from blood of healthy volunteers, but also from cancer patients with multiple myeloma. ${ }^{190}$ The NK cells are not the first targets of this dendrimer, but another key population of human innate immunity, the monocytes, in which this dendrimer penetrates in less than one minute, to activate them through an anti-inflammatory pathway. ${ }^{58,191}$ In view of the multiple properties of this dendrimer, a structure/activity relationship has been developed, by 
varying first the type and number of terminal functions, ${ }^{18,20,64,111}$ then the internal structure ${ }^{62}$ but the most efficient compound remained the first generation phosphorus dendrimer with azabisphosphonate terminal functions. This dendrimer induces an anti-osteoclastic activity on mouse and human cells, and inhibited the development of inflammatory arthritis in two mouse models, to which it was either injected (ip) or given orally (per os) with an almost analogous efficiency. ${ }^{192}$ This dendrimer was tested in other inflammatory diseases, such as Uveitis ${ }^{193}$ and neuroinflammation, ${ }^{194}$ and its preclinical safety was estimated by repeated injections to monkeys. ${ }^{195}$ A start-up (IMD-Pharma ${ }^{196}$ ) has been created recently with the hope of developing this dendrimer towards a Phase 1 clinical trial.

\subsection{Conclusion}

Phosphorus-containing dendrimers, especially phosphorhydrazone dendrimers offers a large number of facilities for modifying them at all levels (core, branches, and terminal functions), in particular to fulfil special requirements for different applications. We have shown different properties in catalysis, for increasing the efficiency (yield and rate), the recovery and re-use, the enantioselectivity, and for decreasing the leaching, the wastes, the temperature, and the quantity of toxic/expensive metals. Diverse uses in the field of nanomaterials have been also displayed, including the synthesis of nano-objects and materials constituted exclusively of dendrimers, the elaboration or protection of nanoparticles thanks to dendrimers, the combination of dendrimers with materials for trapping pollutants and for providing supports for cells culture, and diverse types of highly sensitive sensors obtained by modifying solid surfaces by dendrimers. This later field has led to the creation of a start-up dedicated to molecular diagnosis. ${ }^{174}$ Biology/nanomedicine is certainly the field in which phosphorus dendrimers have displayed the largest number of properties. Indeed, several types of phosphorus dendrimers are able to fight against different diseases, including in vivo, such as the prion disease, with a cationic generation 4 dendrimer, the acute lung inflammation disease, with a third generation mannose-capped dendrimer, and the models of rheumatoid arthritis and of multiple sclerosis diseases, using an anionic first generation dendrimer, which has also led to the creation of a start-up. ${ }^{196}$ In view of all these properties, we hope that phosphorus dendrimers may overcome "the dendrimer paradox: high medical expectations but poor clinical translation". ${ }^{197}$

\section{Acknowledgement}

Thanks are due to the CNRS for financial support.

\section{References}


1. A.M. Caminade, Chem. Soc. Rev. 2016, 45, 5174.

2. K. Rengan and R. Engel, J. Chem. Soc.-Chem. Commun. 1990, 1084.

3. N. Launay, A.M. Caminade, R. Lahana and J.P. Majoral, Angew. Chem. Int. Ed. Engl. 1994, 33, 1589.

4. A. Miedaner, C.J. Curtis, R.M Barkley and D.L Dubois, Inorg. Chem. 1994, 33, 5482.

5. M. Petrucci-Samija, V. Guillemette, M. Dasgupta and A.K. Kakkar, J. Am. Chem. Soc. 1999, $121,3248$.

6. R.H.E. Hudson and M.J. Damha, J. Am. Chem. Soc. 1993, 115, 2119.

7. R. Roy, Topics Curr. Chem. 1997, 187, 241.

8. G.M. Salamonczyk, M. Kuznikowski and E. Poniatowska, Chem. Commun. 2001, 2202.

9. E. Okutan, B. Cosut, S.B. Kayiran, M. Durmus, A. Kilic and S. Yesilot, Polyhedron, 2014, 67, 344.

10. L. Abbassi, Y.M. Chabre, N. Kottari, A.A. Arnold, S. Andre, J. Josserand, H.J. Gabius and R. Roy, Polymer Chem. 2015, 6, 7666.

11. F. Sournies, F. Crasnier, M. Graffeuil, J.P. Faucher, R. Lahana, M.C. Labarre and J.F. Labarre, Angew. Chem.-Int. Edit. Engl. 1995, 34, 578.

12. N. Launay, A.M. Caminade and J.P. Majoral, J. Am. Chem. Soc., 1995, 117, 3282.

13. M. Slany, M. Bardaji, M.J. Casanove, A.M. Caminade, J.P. Majoral and B. Chaudret, J. Am. Chem. Soc. 1995, 117, 9764.

14. M.L. Lartigue, B. Donnadieu, C. Galliot, A.M. Caminade, J.P. Majoral and J.P. Fayet, Macromolecules, 1997, 30, 7335.

15. N. Launay, A.M. Caminade and J.P. Majoral, J. Organomet. Chem. 1997, 529, 51.

16. A.M. Caminade, A. Hameau and J.P. Majoral, Dalton Trans. 2016, 45, 1810.

17. M. Keller, V. Colliere, O. Reiser, A.M. Caminade, J.P. Majoral and A. Ouali, Angew. Chem. Int. Ed. 2013, 52, 3626.

18. J. Ledall, S. Fruchon, M. Garzoni, G.M. Pavan, A.M. Caminade, C.O. Turrin, M. Blanzat and R. Poupot, Nanoscale, 2015, 7, 17672.

19. T.R. Krishna, M. Parent, M.H.V. Werts, L. Moreaux, S. Gmouh, S. Charpak, A.M. Caminade, J.P. Majoral and M. Blanchard-Desce, Angew. Chem. Int. Ed. 2006, 45, 4645.

20. O. Rolland, L. Griffe, M. Poupot, A. Maraval, A. Ouali, Y. Coppel, J.J. Fournie, G. Bacquet, C.O. Turrin, A.M. Caminade, J.P. Majoral and R. Poupot, Chem.-Eur. J. 2008, 14, 4836.

21. J. Leclaire, Y. Coppel, A.M. Caminade and J.P. Majoral, J. Am. Chem. Soc. 2004, 126, 2304.

22. J. Leclaire, R. Dagiral, S. Fery-Forgues, Y. Coppel, B. Donnadieu, A.M. Caminade and J.P. Majoral, J. Am. Chem. Soc. 2005, 127, 15762.

23. G. Spataro, F. Malecaze, C.O. Turrin, V. Soler, C. Duhayon, P.P. Elena, J.P. Majoral and A.M. Caminade, Eur. J. Med. Chem. 2010, 45, 326. 
24. V. Maraval, R. Laurent, B. Donnadieu, M. Mauzac, A.M. Caminade and J.P. Majoral, J. Am. Chem. Soc. 2000, 122, 2499.

25. G. Magro, P. Marchand, R. M. Sebastian, C. Guyard-Duhayon, A.M. Caminade and J.P. Majoral, Eur. J. Org. Chem. 2005, 1340.

26. R.M. Sebastian, J.C. Blais, A.M. Caminade and J.P. Majoral, Chem.-Eur. J. 2002, 8, 2172.

27. C.O. Turrin, J. Chiffre, D. de Montauzon, J.C. Daran, A.M. Caminade, E. Manoury, G. Balavoine and J.P. Majoral, Macromolecules, 2000, 33, 7328.

28. C.O. Turrin, J. Chiffre, D. de Montauzon, G. Balavoine, E. Manoury, A.M. Caminade and J.P. Majoral, Organometallics, 2002, 21, 1891.

29. E.R. de Jong, E. Manoury, J.C. Daran, C.O. Turrin, J. Chiffre, A. Sournia-Saquet, W. Knoll, J.P. Majoral and A.M. Caminade, J. Organomet. Chem. 2012, 718, 22.

30. O. Mongin, C. Rouxel, A.C. Robin, A. Pla-Quintana, T.R. Krishna, G. Recher, F. Tiaho, A.M. Caminade, J.P. Majoral and M. Blanchard-Desce, in Nanobiosystems: Processing, Characterization, and Applications, eds. E. M. Heckman, T. B. Singh and J. Yoshida, Spie-Int Soc Optical Engineering, Bellingham, 2008, vol. 7040.

31. S. Mignani, N. El Brahmi, L. Eloy, J. Poupon, V. Nicolas, A. Steinmetz, S. El Kazzouli, M.M. Bousmina, M. Blanchard-Desce, A.M. Caminade, J.P. Majoral and T. Cresteil, Eur. J. Med. Chem. 2017, 132, 142.

32. P. Servin, C. Rebout, R. Laurent, M. Peruzzini, A.M. Caminade and J.P. Majoral, Tetrahedron Lett. $2007,48,579$.

33. H. Dib, C. Rebout, R. Laurent, S. Mallet-Ladeira, A. Sournia-Saquet, M.B. Sarosi, E. Hey-Hawkins, J.P. Majoral, B. Delavaux-Nicot and A.M. Caminade, Chem.-Eur. J. 2016, 22, 10736.

34. C. Galliot, D. Prevote, A.M. Caminade and J.P. Majoral, J. Am. Chem. Soc. 1995, 117, 5470.

35. C. Larre, A.M. Caminade and J.P. Majoral, Angew. Chem.-Int. Edit. Engl. 1997, 36, 596.

36. R.M. Sebastian, G. Magro, A.M. Caminade and J.P. Majoral, Tetrahedron, 2000, 56, 6269.

37. L. Brauge, G. Magro, A.M. Caminade and J.P. Majoral, J. Am. Chem. Soc. 2001, 123, 6698. Correction: ibid. J. Am. Chem. Soc. 2001, 123, 8446.

38. V. Maraval, J. Pyzowski, A.M. Caminade and J.P. Majoral, J. Org. Chem. 2003, 68, 6043.

39. V. Maraval, A.M. Caminade, J.P. Majoral and J.C. Blais, Angew. Chem. Int. Ed. 2003, 42, 1822.

40. S. Merino, L. Brauge, A.M. Caminade, J.P. Majoral, D. Taton and Y. Gnanou, Chem.-Eur. J. 2001, 7, 3095.

41. C. Larre, B. Donnadieu, A.M. Caminade and J.P. Majoral, J. Am. Chem. Soc. 1998, 120, 4029.

42. C. Larre, D. Bressolles, C. Turrin, B. Donnadieu, A.M. Caminade and J.P. Majoral, J. Am. Chem. Soc. 1998, 120, 13070.

43. L. Brauge, A.M. Caminade, J.P. Majoral, S. Slomkowski and M. Wolszczak, Macromolecules, 2001, 34, 
5599.

44. C. Galliot, C. Larre, A.M. Caminade and J.P. Majoral, Science, 1997, 277, 1981.

45. C. Larre, B. Donnadieu, A.M. Caminade and J.P. Majoral, Chem.-Eur. J. 1998, 4, 2031.

46. V. Maraval, R. Laurent, S. Merino, A.M. Caminade and J.P. Majoral, Eur. J. Org. Chem. 2000, 3555.

47. S. Fuchs, A. Pla-Quintana, S. Mazeres, A.M. Caminade and J.P. Majoral, Org. Lett. 2008, 10, 4751.

48. A.M. Caminade, R. Laurent, B. Delavaux-Nicot and J.P. Majoral, New J. Chem. 2012, 36, 217.

49. V. Maraval, A. Maraval, G. Spataro, A.M. Caminade, J.P. Majoral, D.H. Kim and W. Knoll, New J. Chem. 2006, 30, 1731.

50. E. Cavero, M. Zablocka, A.M. Caminade and J.P. Majoral, Eur. J. Org. Chem. 2010, 2759.

51. N. Katir, J.P. Majoral, A. El Kadib, A.M. Caminade and M. Bousmina, Eur. J. Org. Chem. 2012, 269.

52. R. Sharma, N. Kottari, Y.M. Chabre, L. Abbassi, T.C. Shiao and R. Roy, Chem. Commun. 2014, 50, 13300.

53. N. Katir, N. El Brahmi, A. El Kadib, S. Mignani, A.M. Caminade, M. Bousmina and J.P. Majoral, Chem.-Eur. J. 2015, 21, 6400.

54. P. Servin, R. Laurent, A. Romerosa, M. Peruzzini, J.P. Majoral and A.M. Caminade, Organometallics, 2008, 27, 2066.

55. M. Keller, A. Hameau, G. Spataro, S. Ladeira, A.M. Caminade, J.P. Majoral and A. Ouali, Green Chem. 2012, 14, 2807.

56. N. El Brahmi, S. El Kazzouli, S.M. Mignani, E. Essassi, G. Aubert, R. Laurent, A.M. Caminade, M.M. Bousmina, T. Cresteil and J.P. Majoral, Mol. Pharm. 2013, 10, 1459.

57. M.F. Ottaviani, N. El Brahmi, M. Cangiotti, C. Coppola, F. Buccella, T. Cresteil, S. Mignani, A.M. Caminade, J.P. Costes and J.P. Majoral, Rsc Advances, 2014, 4, 36573.

58. M. Poupot, L. Griffe, P. Marchand, A. Maraval, O. Rolland, L. Martinet, F.E. L'Faqihi-Olive, C.O. Turrin, A.M. Caminade, J.J. Fournie, J.P. Majoral and R. Poupot, FASEB J. 2006, 20, 2339.

59. L. Griffe, M. Poupot, P. Marchand, A. Maraval, C.O. Turrin, O. Rolland, P. Metivier, G. Bacquet, J.J. Fournie, A.M. Caminade, R. Poupot and J.P. Majoral, Angew. Chem. Int. Ed. 2007, 46, 2523.

60. A. Perez-Anes, G. Spataro, Y. Coppel, C. Moog, M. Blanzat, C.O. Turrin, A.M. Caminade, I. Rico-Lattes and J.P. Majoral, Org. Biomol. Chem. 2009, 7, 3491.

61. A. Perez-Anes, C. Stefaniu, C. Moog, J.P. Majoral, M. Blanzat, C.O. Turrin, A.M. Caminade and I. RicoLattes, Bioorg. Med. Chem. 2010, 18, 242.

62. A.M. Caminade, S. Fruchon, C.O. Turrin, M. Poupot, A. Ouali, A. Maraval, M. Garzoni, M. Maly, V. Furer, V. Kovalenko, J.P. Majoral, G.M. Pavan and R. Poupot, Nature Communications, 2015, 6, 7722.

63. O. Rolland, C.O. Turrin, G. Bacquet, R. Poupot, M. Poupot, A.M. Caminade and J.P. Majoral, Tetrahedron Lett. 2009, 50, 2078. 
64. F. Ielasi, J. Ledall, A. Perez-Anes, S. Fruchon, A.M. Caminade, R. Poupot, C.O. Turrin and M. Blanzat, Phys. Chem. Chem. Phys. 2016, 18, 21871.

65. E. Blattes, A. Vercellone, H. Eutamene, C.O. Turrin, V. Theodorou, J.P. Majoral, A.M. Caminade, J. Prandi, J. Nigou and G. Puzo, Proc. Natl. Acad. Sci. U. S. A. 2013, 110, 8795.

66. G. Franc, S. Mazeres, C.O. Turrin, L. Vendier, C. Duhayon, A.M. Caminade and J.P. Majoral, J. Org. Chem. 2007, 72, 8707.

67. E. Martinez-Ferrero, G. Franc, S. Mazeres, C.O. Turrin, U. Boissiere, A.M. Caminade, J.P. Majoral and C. Sanchez, Chem.-Eur. J. 2008, 14, 7658.

68. A. Hameau, S. Fuchs, R. Laurent, J.P. Majoral and A.M. Caminade, Beilstein J. Org. Chem. 2011, 7, 1577.

69. Y.Q. Wei, R. Laurent, J.P. Majoral and A.M. Caminade, Arkivoc, 2010, 318.

70. C.O. Turrin, J. Chiffre, J.C. Daran, D. de Montauzon, A.M. Caminade, E. Manoury, G. Balavoine and J.P. Majoral, Tetrahedron, 2001, 57, 2521.

71. L. Routaboul, S. Vincendeau, C.O. Turrin, A.M. Caminade, J.P. Majoral, J.C. Daran and E. Manoury, J. Organomet. Chem. 2007, 692, 1064.

72. P. Neumann, H. Dib, A. Sournia-Saquet, T. Grell, M. Handke, A.M. Caminade and E. Hey-Hawkins, Chem.-Eur. J. 2015, 21, 6590.

73. P. Neumann, H. Dib, A.M. Caminade and E. Hey-Hawkins, Angew. Chem. Int. Ed., 2015 54, 311.

74. A. Gissibl, C. Padie, M. Hager, F. Jaroschik, R. Rasappan, E. Cuevas-Yanez, C.O. Turrin, A.M. Caminade, J.P. Majoral and O. Reiser, Org. Lett. 2007, 9, 2895.

75. M. Keller, A. Perrier, R. Linhardt, L. Travers, S. Wittmann, A.M. Caminade, J.P. Majoral, O. Reiser and A. Ouali, Adv. Synth. Catal. 2013, 355, 1748.

76. G. Franc, C.O. Turrin, E. Cavero, J.P. Costes, C. Duhayon, A.M. Caminade and J.P. Majoral, Eur. J. Org. Chem. 2009, 4290.

77. N. El Brahmi, S.M. Mignani, J. Caron, S. El Kazzouli, M.M. Bousmina, A.M. Caminade, T. Cresteil and J.P. Majoral, Nanoscale, 2015, 7, 3915.

78. S. Mignani, N. El Brahmi, S. El Kazzouli, L. Eloy, D. Courilleau, J. Caron, M.M. Bousmina, A.M. Caminade, T. Cresteil and J.P. Majoral, Eur. J. Med. Chem. 2016, 122, 656.

79. C. O. Turrin, V. Maraval, J. Leclaire, E. Dantras, C. Lacabanne, A.M. Caminade and J.P. Majoral, Tetrahedron, 2003, 59, 3965.

80. O. Mongin, C. Rouxel, J. M. Vabre, Y. Mir, A. Pla-Quintana, Y.Q. Wei, A.M. Caminade, J.P. Majoral and M. Blanchard-Desce, in Nanobiosystems: Processing, Characterization, and Applications Ii, eds. N. Kobayashi, F. Ouchen and I. Rau, Spie-Int Soc Optical Engineering, Bellingham, 2009, vol. 7403.

81. M. Koprowski, R.M. Sebastian, V. Maraval, M. Zablocka, V. Cadierno, B. Donnadieu, A. Igau, A.M. 
Caminade and J.P. Majoral, Organometallics, 2002, 21, 4680.

82. L. Garcia, A. Roglans, R. Laurent, J.P. Majoral, A. Pla-Quintana and A.M. Caminade, Chem. Commun. 2012, 48, 9248.

83. A. Ouali, R. Laurent, A.M. Caminade, J.P. Majoral and M. Taillefer, J. Am. Chem. Soc. 2006, 128, 15990.

84. M. Keller, M. Ianchuk, S. Ladeira, M. Taillefer, A.M. Caminade, J.P. Majoral and A. Ouali, Eur. J. Org. Chem. 2012, 1056.

85. A. Perrier, M. Keller, A.M. Caminade, J.P. Majoral and A. Ouali, Green Chem. 2013, 15, 2075.

86. O. Mongin, T.R. Krishna, M.H.V. Werts, A.M. Caminade, J.P. Majoral and M. Blanchard-Desce, Chem. Commun., 2006, 915.

87. F. Terenziani, V. Parthasarathy, A. Pla-Quintana, T. Maishal, A.M. Caminade, J.P. Majoral and M. Blanchard-Desce, Angew. Chem. Int. Ed. 2009, 48, 8691.

88. P. Marchand, L. Griffe, A.M. Caminade, J.P. Majoral, M. Destarac and F. Leising, Org. Lett. 2004, 6, 1309.

89. V. Darcos, A. Dureault, D. Taton, Y. Gnanou, P. Marchand, A.M. Caminade, J.P. Majoral, M. Destarac and F. Leising, Chem. Commun., 2004, 2110.

90. C. Hadad, J.P. Majoral, J. Muzart, A.M. Caminade and S. Bouquillon, Tetrahedron Lett. 2009, 50, 1902.

91. M.A. Lacour, M. Zablocka, A.M. Caminade, M. Taillefer and J.P. Majoral, Tetrahedron Lett. 2009, 50, 4870.

92. J. Rull, M. Casals, R.M. Sebastian, A. Vallribera, J.P. Majoral and A.M. Caminade, Chemcatchem, 2015, 7, 2698.

93. J. Rull, J.J. Jara, R.M. Sebastian, A. Vallribera, C. Najera, J.P. Majoral and A.M. Caminade, Chemcatchem, 2016, 8, 2049.

94. E. Folgado, M. Guerre, C. Bijani, V. Ladmiral, A.M. Caminade, B. Ameduri and A. Ouali, Polymer Chemistry, 2016, 7, 5625.

95. N. Launay, M. Slany, A.M. Caminade and J.P. Majoral, J. Org. Chem. 1996, 61, 3799.

96. C. Loup, M.A. Zanta, A.M. Caminade, J.P. Majoral and B. Meunier, Chem.-Eur. J. 1999, 5, 3644.

97. T. Wasiak, M. Ionov, K. Nieznanski, H. Nieznanska, O. Klementieva, M. Granell, J. Cladera, J.P. Majoral, A.M. Caminade and B. Klajnert, Mol. Pharm. 2012, 9, 458.

98. T. Wasiak, M. Marcinkowska, I. Pieszynski, M. Zablocka, A.M. Caminade, J.P. Majoral and B. KlajnertMaculewicz, New J. Chem. 2015, 39, 4852.

99. C. Padie, M. Maszewska, K. Majchrzak, B. Nawrot, A.M. Caminade and J.P. Majoral, New J. Chem. 2009, 33, 318.

100. D. Prevote, B. Donnadieu, M. Moreno-Manas, A.M. Caminade and J.P. Majoral, Eur. J. Org. Chem. 
1999, 1701.

101. M. L. Lartigue, A.M. Caminade and J.P. Majoral, Tetrahedron-Asymmetry, 1997, 8, 2697.

102. R. Laurent, A.M. Caminade and J.P. Majoral, Tetrahedron Lett. 2005, 46, 6503.

103. L. Brauge, G. Veriot, G. Franc, R. Deloncle, A.M. Caminade and J.P. Majoral, Tetrahedron, 2006, 62, 11891.

104. R. Goller, J.P. Vors, A.M. Caminade and J.P. Majoral, Tetrahedron Lett. 2001, 42, 3587.

105. E. Badetti, V. Lloveras, K. Wurst, R.M. Sebastian, A.M. Caminade, J.P. Majoral, J. Veciana and J. Vidal-Gancedo, Org. Lett. 2013, 15, 3490.

106. E. Badetti, V. Lloveras, J.L. Munoz-Gomez, R.M. Sebastian, A.M. Caminade, J.P. Majoral, J. Veciana and J. Vidal-Gancedo, Macromolecules, 2014, 47, 7717.

107. E. Badetti, A.M. Caminade, J.P. Majoral, M. Moreno-Manas and R.M. Sebastian, Langmuir, 2008, 24, 2090.

108. G. Franc, E. Badetti, V. Colliere, J.P. Majoral, R.M. Sebastian and A.M. Caminade, Nanoscale, 2009, 1, 233.

109. C.A. Hincapie, R.M. Sebastian, J. Barbera, J.L. Serrano, T. Sierra, J.P. Majoral and A.M. Caminade, Chem.-Eur. J. 2014, 20, 17047.

110. D. Prevote, A.M. Caminade and J.P. Majoral, J. Org. Chem. 1997, 62, 4834.

111. P. Marchand, L. Griffe, M. Poupot, C.O. Turrin, G. Bacquet, J.J. Fournie, J.P. Majoral, R. Poupot and A.M. Caminade, Bioorg. Med. Chem. Lett. 2009, 19, 3963.

112. A. Hameau, S. Fruchon, C. Bijani, A. Barducci, M. Blanzat, R. Poupot, G.M. Pavan, A.M. Caminade and C.O. Turrin, Journal of Polymer Science Part a-Polymer Chemistry, 2015, 53, 761.

113. C. Marmillon, F. Gauffre, T. Gulik-Krzywicki, C. Loup, A.M. Caminade, J.P. Majoral, J.P. Vors and E. Rump, Angew. Chem. Int. Ed. 2001, 40, 2626.

114. A. El Ghzaoui, F. Gauffre, A.M. Caminade, J.P. Majoral and H. Lannibois-Drean, Langmuir, 2004, 20, 9348.

115. C. Larpent, C. Genies, A.P.D. Delgado, A.M. Caminade, J.P. Majoral, J.F. Sassi and F. Leising, Chem. Commun. 2004, 1816.

116. M. Slany, M. Bardaji, A.M. Caminade, B. Chaudret and J.P. Majoral, Inorg. Chem. 1997, 36, 1939.

117. M. Bardaji, M. Kustos, A.M. Caminade, J.P. Majoral and B. Chaudret, Organometallics, 1997, 16, 403.

118. M. Bardaji, A.M. Caminade, J.P. Majoral and B. Chaudret, Organometallics, 1997, 16, 3489.

119. V. Maraval, R. Laurent, A.M. Caminade and J.P. Majoral, Organometallics, 2000, 19, 4025.

120. G. Schmid, W. Meyer-Zaika, R. Pugin, T. Sawitowski, J.P. Majoral, A.M. Caminade and C.O. Turrin, Chem.-Eur. J. 2000, 6, 1693. 
121. G. Schmid, E. Emmrich, J.P. Majoral and A.M. Caminade, Small, 2005, 1, 73.

122. D. Prevote, S. LeRoy-Gourvennec, A.M. Caminade, S. Masson and J.P. Majoral, Synthesis-Stuttgart, $1997,1199$.

123. F. Le Derf, E. Levillain, G. Trippe, A. Gorgues, M. Salle, R.M. Sebastian, A.M. Caminade and J.P. Majoral, Angew. Chem. Int. Ed. 2001, 40, 224.

124. R.M. Sebastian, A.M. Caminade, J.P. Majoral, E. Levillain, L. Huchet and J. Roncali, Chem. Commun. 2000, 507.

125. V. Cadierno, A. Igau, B. Donnadieu, A.M. Caminade and J.P. Majoral, Organometallics, 1999, 18, 1580.

126. G. Soler-Illia, L. Rozes, M.K. Boggiano, C. Sanchez, C.O. Turrin, A.M. Caminade and J.P. Majoral, Angew. Chem. Int. Ed. 2000, 39, 4250.

127. A. Kanibolotsky, S. Roquet, M. Cariou, P. Leriche, C.O. Turrin, R. de Bettignies, A.M. Caminade, J.P. Majoral, V. Khodorkovsky and A. Gorgues, Org. Lett. 2004, 6, 2109.

128. P. Servin, R. Laurent, L. Gonsalvi, M. Tristany, M. Peruzzini, J.P. Majoral and A.M. Caminade, Dalton Trans. 2009, 4432.

129. M. Blanzat, C.O. Turrin, E. Perez, I. Rico-Lattes, A.M. Caminade and J.P. Majoral, Chem. Commun. 2002, 1864.

130. M. Blanzat, C.O. Turrin, A.M. Aubertin, C. Couturier-Vidal, A.M. Caminade, J.P. Majoral, I. RicoLattes and A. Lattes, ChemBioChem, 2005, 6, 2207.

131. M.L. Lartigue, M. Slany, A.M. Caminade and J.P. Majoral, Chem.-Eur. J. 1996, 2, 1417.

132. D. Riegert, A. Pla-Quintana, S. Fuchs, R. Laurent, C.O. Turrin, C. Duhayon, J.P. Majoral, A. Chaumonnot and A.M. Caminade, Eur. J. Org. Chem. 2013, 2013, 5414.

133. G. Franc, E. Badetti, C. Duhayon, Y. Coppel, C.O. Turrin, J.P. Majoral, R.M. Sebastian and A.M. Caminade, New J. Chem. 2010, 34, 547.

134. M. Slany, A.M. Caminade and J.P. Majoral, Tetrahedron Lett. 1996, 37, 9053.

135. N. El Brahmi, S. El Kazzouli, S. Mignani, R. Laurent, S. Ladeira, A.M. Caminade, M. Bousmina and J.P. Majoral, Tetrahedron, 2017, 73, 1331.

136. P. Servin, R. Laurent, H. Dib, L. Gonsalvi, M. Peruzzini, J.P. Majoral and A.M. Caminade, Tetrahedron Lett. 2012, 53, 3876.

137. N.G. Garcia-Pena, A.M. Caminade, A. Ouali, R. Redon and C.O. Turrin, Rsc Advances, 2016, 6, 64557.

138. A.M. Caminade, A. Ouali, R. Laurent, C.O. Turrin and J.P. Majoral, Coord. Chem. Rev. 2016, 308, 478.

139. A.M. Caminade, A. Ouali, R. Laurent, C.O. Turrin and J.P. Majoral, Chem. Soc. Rev. 2015, 44, 
3890.

140. A.M. Caminade, P. Servin, R. Laurent and J.P. Majoral, Chem. Soc. Rev. 2008, 37, 56.

141. A.M. Caminade, A. Ouali, M. Keller and J.P. Majoral, Chem. Soc. Rev. 2012, 41, 4113.

142. C.O. Turrin, V. Maraval, A.M. Caminade, J.P. Majoral, A. Mehdi and C. Reye, Chem. Mater. 2000, 12,3848 .

143. A.M. Caminade and J.P. Majoral, Acc. Chem. Res. 2004, 37, 341.

144. A.M. Caminade and J.P. Majoral, J. Mater. Chem. 2005, 15, 3643.

145. W. Knoll, A.M. Caminade, K. Char, H. Duran, C.L. Feng, A. Gitsas, D.H. Kim, A. Lau, T.D. Lazzara, J.P. Majoral, M. Steinhart, B. Yameen and X.H. Zhong, Small, 2011, 7, 1384.

146. A.M. Caminade and J.P. Majoral, Chem. Soc. Rev. 2010, 39, 2034.

147. D.H. Kim, P. Karan, P. Goring, J. Leclaire, A.M. Caminade, J.P. Majoral, U. Gosele, M. Steinhart and W. Knoll, Small, 2005, 1, 99.

148. C.L. Feng, X.H. Zhong, M. Steinhart, A.M. Caminade, J.P. Majoral and W. Knoll, Adv. Mater. 2007, 19, 1933.

149. C.L. Feng, X.H. Zhong, M. Steinhart, A.M. Caminade, J.P. Majoral and W. Knoll, Small, 2008, 4, 566.

150. T.D. Lazzara, K.H.A. Lau, A.I. Abou-Kandil, A.M. Caminade, J.P. Majoral and W. Knoll, ACS Nano, 2010, 4, 3909.

151. B.S. Kim, O.V. Lebedeva, D.H. Kim, A.M. Caminade, J.P. Majoral, W. Knoll and O.I. Vinogradova, Langmuir, 2005, 21, 7200.

152. B.S. Kim, O.V. Lebedeva, M.K. Park, W. Knoll, A.M. Caminade, J.P. Majoral and O.I. Vinogradova, Polymer, 2010, 51, 4525.

153. B.S. Kim, O.V. Lebedeva, K. Koynov, H.F. Gong, A.M. Caminade, J.P. Majoral and O.I. Vinogradova, Macromolecules, 2006, 39, 5479.

154. C.L. Feng, A.M. Caminade, J.P. Majoral, J.J. Gu, S.M. Zhu, H.L. Su, X.B. Hu and D. Zhang, Analyst, 2010, 135, 2939.

155. C.L. Feng, A.M. Caminade, J.P. Majoral and D. Zhang, J. Mater. Chem. 2010, $20,1438$.

156. Y. Brahmi, N. Katir, A. Hameau, A. Essoumhi, E. Essassi, A.M. Caminade, M. Bousmina, J.P. Majoral and A. El Kadib, Chem. Commun. 2011, 47, 8626.

157. Y. Brahmi, N. Katir, M. Ianchuk, V. Colliere, E. Essassi, A. Ouali, A.M. Caminade, M. Bousmina, J.P. Majoral and A. El Kadib, Nanoscale, 2013, 5, 2850.

158. A. Hameau, V. Colliere, J. Grimoud, P. Fau, C. Roques, A.M. Caminade and C.O. Turrin, RSC Advances, 2013, 3, 19015.

159. D. Riegert, L. Bareille, R. Laurent, J.P. Majoral, A.M. Caminade and A. Chaumonnot, Eur. J. Inorg. 
Chem. 2016, 3103.

160. A. Beraa, M. Hajjaji, R. Laurent, B. Delavaux-Nicot and A.M. Caminade, Desalin. Water Treat. 2016, 57, 14290.

161. A. Beraa, M. Hajjaji, R. Laurent and A.M. Caminade, Appl. Clay Sci. 2017, 136, 142.

162. J.L. Hernandez-Lopez, H.L. Khor, A.M. Caminade, J.P. Majoral, S. Mittler, W. Knoll and D.H. Kim, Thin Solid Films, 2008, 516, 1256.

163. E.R. de Jong, N. Deloch, W. Knoll, C.O. Turrin, J.P. Majoral, A.M. Caminade and I. Koper, New J. Chem. 2015, 39, 7194.

164. A.M. Caminade, C. Padie, R. Laurent, A. Maraval and J.P. Majoral, Sensors, 2006, 6, 901.

165. A.V. Gerasimov, M.A. Ziganshin, A.E. Vandyukov, V.I. Kovalenko, V.V. Gorbatchuk, A.M. Caminade and J.P. Majoral, J. Colloid Interface Sci. 2011, 360, 204.

166. W.B. Zhao, J. Park, A.M. Caminade, S.J. Jeong, Y.H. Jang, S.O. Kim, J.P. Majoral, J. Cho and D.H. Kim, J. Mat. Chem. 2009, 19, 2006.

167. Y.M. Yu, C.L. Feng, A.M. Caminade, J.P. Majoral and W. Knoll, Langmuir, 2009, 25, 13680.

168. C.L. Feng, M.Z. Yin, D. Zhang, S.M. Zhu, A.M. Caminade, J.P. Majoral and K. Mullen, Macromol. Rapid Commun. 2011, 32, 679.

169. E. Jauvert, E. Dague, M. Severac, L. Ressier, A.M. Caminade, J.P. Majoral and E. Trevisiol, Sens. Actuator B-Chem. 2012, 168, 436.

170. V. Le Berre, E. Trevisiol, A. Dagkessamanskaia, S. Sokol, A.M. Caminade, J.P. Majoral, B. Meunier and J. Francois, Nucleic Acids Res. 2003, 31, 8.

171. E. Trevisiol, V. Le Berre-Anton, J. Leclaire, G. Pratviel, A.M. Caminade, J.P. Majoral, J.M. Francois and B. Meunier, New J. Chem. 2003, 27, 1713.

172. L. Nicu, M. Guirardel, F. Chambosse, P. Rougerie, S. Hinh, E. Trevisiol, J.M. Francois, J.P. Majoral, A.M. Caminade, E. Cattan and C. Bergaud, Sens. Actuator B-Chem. 2005, 110, 125.

173. B. Chaize, M. Nguyen, T. Ruysschaert, V. le Berre, E. Trevisiol, A.M. Caminade, J.P. Majoral, G. Pratviel, B. Meunier, M. Winterhalter and D. Fournier, Bioconjugate Chem. 2006, 17, 245.

174. $\quad$ www.dendris.fr

175. A.M. Caminade, Chem. Commun. 2017, 53, 9830.

176. D. Shcharbin, V. Dzmitruk, A. Shakhbazau, N. Goncharova, I. Seviaryn, S. Kosmacheva, M. Potapnev, E. Pedziwiatr-Werbicka, M. Bryszewska, M. Talabaev, A. Chernov, V. Kulchitsky, A.M. Caminade and J.P. Majoral, Pharmaceutics, 2011, 3, 458.

177. J. Kazmierczak-Baranska, A. Pietkiewicz, M. Janicka, Y.Q. Wei, C.O. Turrin, J.P. Majoral, B. Nawrot and A.M. Caminade, Nucleosides Nucleotides \& Nucleic Acids, 2010, 29, 155.

178. M. Maszewska, J. Leclaire, M. Cieslak, B. Nawrot, A. Okruszek, A.M. Caminade and J.P. Majoral, 
Oligonucleotides, 2003, 13, 193.

179. V. Briz, M. J. Serramia, R. Madrid, A. Hameau, A.M. Caminade, J.P. Majoral and M.A. MunozFernandez, Curr. Med. Chem., 2012, 19, 5044.

180. E. Vacas-Cordoba, H. Bastida, M. Pion, A. Hameau, M. Ionov, M. Bryszewska, A.M. Caminade, J.P. Majoral and M.A. Munoz-Fernandez, Curr. Med. Chem. 2014, 21, 1898.

181. A. Shakhbazau, C. Mohanty, D. Shcharbin, M. Bryszewska, A.M. Caminade, J.P. Majoral, J. Alant and R. Midha, J. Controlled Release, 2013, 172, 841.

182. J. Solassol, C. Crozet, V. Perrier, J. Leclaire, F. Beranger, A.M. Caminade, B. Meunier, D. Dormont, J.P. Majoral and S. Lehmann, J. Gen. Virol. 2004, 85, 1791.

183. B. Klajnert, M. Cangiotti, S. Calici, M. Ionov, J.P. Majoral, A.M. Caminade, J. Cladera, M. Bryszewska and M.F. Ottaviani, New J. Chem. 2009, 33, 1087.

184. M.F. Ottaviani, R. Mazzeo, M. Cangiotti, L. Fiorani, J.P. Majoral, A.M. Caminade, E. Pedziwiatr, M. Bryszewska and B. Klajnert, Biomacromolecules, 2010, 11, 3014.

185. B. Klajnert, M. Cangiotti, S. Calici, J.P. Majoral, A.M. Caminade, J. Cladera, M. Bryszewska and M.F. Ottaviani, Macromol. Biosci. 2007, 7, 1065.

186. K. Milowska, T. Gabryelak, M. Bryszewska, A.M. Caminade and J.P. Majoral, Int. J. Biol. Macromol. 2012, 50, 1138.

187. K. Milowska, A. Szwed, M. Zablocka, A.M. Caminade, J.P. Majoral, S. Mignani, T. Gabryelak and M. Bryszewska, Int. J. Pharm. 2014, 474, 42.

188. K. Ciepluch, N. Katir, A. El Kadib, A. Felczak, K. Zawadzka, M. Weber, B. Klajnert, K. Lisowska, A.M. Caminade, M. Bousmina, M. Bryszewska and J.P. Majoral, Mol. Pharm. 2012, 9, 448.

189. D. Portevin, M. Poupot, O. Rolland, C.O. Turrin, J.J. Fournie, J.P. Majoral, A.M. Caminade and R. Poupot, J. Transl. Med. 2009, 7, 13.

190. M. Poupot, C.O. Turrin, A.M. Caminade, J.J. Fournie, M. Attal, R. Poupot and S. Fruchon, Nanomedicine-Nanotechnology Biology and Medicine, 2016, 12, 2321.

191. S. Fruchon, M. Poupot, L. Martinet, C.O. Turrin, J.P. Majoral, J.J. Fournie, A.M. Caminade and R. Poupot, J. Leukocyte Biol. 2009, 85, 553.

192. M. Hayder, M. Poupot, M. Baron, D. Nigon, C.O. Turrin, A.M. Caminade, J.P. Majoral, R.A. Eisenberg, J.J. Fournie, A. Cantagrel, R. Poupot and J.L. Davignon, Sci. Transl. Med. 2011, 3, 11.

193. S. Fruchon, A.M. Caminade, C. Abadie, J.L. Davignon, J.M. Combette, C.O. Turrin and R. Poupot, Molecules, 2013, 18, 9305.

194. M. Hayder, M. Varilh, C.O. Turrin, A. Saoudi, A.M. Caminade, R. Poupot and R.S. Liblau, Biomacromolecules, 2015, 16, 3425.

195. S. Fruchon, S. Mouriot, T. Thiollier, C. Grandin, A.M. Caminade, C.O. Turrin, H. Contamin and R. 
Poupot, Nanotoxicology, 2015, 9, 433.

196. www.imd-pharma.com

197. S. Svenson, Chem. Soc. Rev. 2015, 44, 4131.

\section{Figure Captions}

Figure 7.1 Diverse types of phosphorus-containing dendrimers, based on P-C bonds (1 - 3), P-O bonds (4 7), or cyclophosphazenes (8 - 10) as branching points.

Figure 7.2 a) method of synthesis of phosphorhydrazone dendrimers; b) different types of cores based on the modification of $\mathrm{N}_{3} \mathrm{P}_{3} \mathrm{Cl}_{6}$, used for the synthesis of phosphorhydrazone dendrimers; c) other types of cores used for the synthesis of phosphorhydrazone dendrimers; d) several types of hydroxyl aldehydes used as branches, in replacement of 4-hydroxybenzaldehyde.

Figure 7.3 Different methods of synthesis of phosphorus dendrimers based on the Staudinger reaction of phosphines with azides.

Figure 7.4 Special types of dendritic structures. a) Reactivity inside dendrimers; b and c) examples of associations of dendrons to produce "Janus" dendrimers; d) example of an "onion peel" dendrimer.

Figure 7.5 An almost exhaustive view of the different types of terminal functions encountered on the surface of phosphorhydrazone dendrimers. a) reaction of phenols on $\mathrm{P}(\mathrm{S}) \mathrm{Cl}_{2}$ terminal functions; b) reaction of amines on $\mathrm{P}(\mathrm{S}) \mathrm{Cl}_{2}$ terminal functions; c) reaction of aldehyde terminal functions; d) selective functionalization of one $\mathrm{Cl}$ of each $\mathrm{P}(\mathrm{S}) \mathrm{Cl}_{2}$ terminal function with amines and phenols. 